\title{
THAI LABOR REQUIREMENTS AND DEVELOPING ENGLISH COMMUNICATION SKILLS IN RANONG PROVINCE
}

\author{
Kanyanant Ananmana \\ Panida Ninaroon \\ Cholpassorn Sittiwarongchai \\ Suwita Pruksaarporn
}

Suan Sunandha Rajabhat University, Bangkok, Thailand

This research aims to study the content requirements when it comes to improvement of English communication skills of Thai laborers who are preparing to enter the labor market in Ranong province, Thailand. This study is a qualitative research since the researchers have used in-depth interviews as the key research instrument and have also applied the triangulation method to check for data validity. The key informants were 20 people including the unemployed Thais and also local university students. The skills in question have been divided into four rather traditional categories:
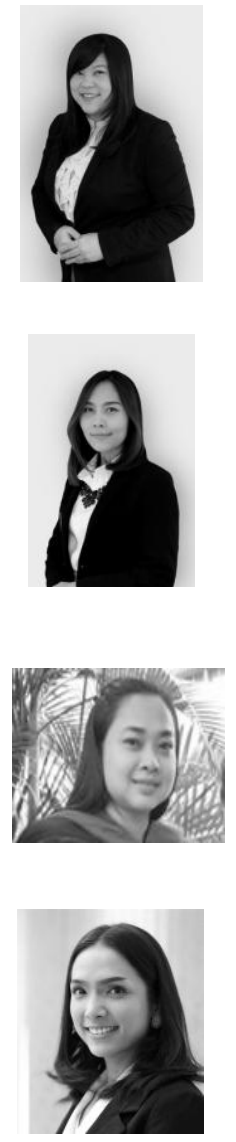

\section{Kanyanant Ananmana}

Lecturer, College of innovation and management,

Suan Sunandha Rajabhat University, Bangkok, Thailand

Science interests: social science (marketing and communication, human resource

management)

E-mail: Kanyanant.an@ssru.ac.th

\section{Panida Ninaroon}

$\mathrm{PhD}$, Lecturer in College of innovation and management, Suan Sunandha Rajabhat University, Bangkok, Thailand

Research interests: social science (Human Resource Management and Organization Management)

E-mail: Panida.ni@ssru.ac.th

\section{Cholpassorn Sitthiwarongchai}

Faculty of Management Science Silpakorn University, Ph.D. candidate interests - management, marketing

E-mail: cholpassorn.si@gmail.com,yumiko_little@hotmail.com

\section{Suwita Pruksaarporn}

Lecturer in College of innovation and management, Suan Sunandha Rajabhat University, Bangkok, Thailand

Research interests: social science (Human Resource Management and Organization Management)

E-mail: Suwita.pr@ssru.ac.th 


\section{THAI LABOR'S REQUIREMENTS FOR}

listening, speaking, reading and writing skills. The research outcomes demonstrate that firstly, most of the unemployed Thai laborers would like to improve their listening skills so that to be able to follow basic instructions and orders at work. Secondly, regarding the speaking skills, most of the informants would like to improve their job interviewing skill. Thirdly, most of Thai laborers would like to develop their reading skill, their key motivation being to read job advertisements. And also - to be able to fill in job application forms is what most of Thai laborers would like to learn. Overall, Thai workers fully admit they are having difficulties in using all four types of skills. However, our research findings also reveals that Thai workers have serious troubles with the speaking skills, mostly because of the wrong usage of English grammar.

The authors of this study would like to recommend both public and private organizations in Ranong area to become more aware of the English communication skill problem of the local Thai workers. The results of this study should be used as a guideline in promoting and developing the programs aimed at improving English communication skills of the current and prospective Thai workers in the province in question.

Keywords: Thai labor requirements, English communication skills; reading; writing; listening; speaking; Ranong province; Thailand.

\section{Introduction}

In the globalization era, it is highly important for the firms to truly leverage on the workforce as a competitive weapon since accumulation of human capital today is probably the most important contributor to economic growth at any level of management (Son, 2010). Strategies aimed at improving workforce productivity and thus driving higher value for the firms has become in focus as well. Firms seek to optimize their workforce through comprehensive human capital development programs so that not only achieve business goals but also guarantee themselves long-term survival and sustainability. To accomplish this undertaking, firms need to invest resources to ensure their employees have sufficient knowledge, skills, and competencies they need to work effectively in a rapidly changing and complex environment (Marimuthu et al., 2009).

In 2015, Thailand has entered the ASEAN community, thus, the use of English language has gained an important role as a medium required for professional advancement as well as a tool to help businesses function more effectively regionwide (Hiranburana, 2017). It is important for the whole of Thai workforce to improve their English communication skills so that they can utilize them in their careers, thus upbuilding and strengthening their own human capital. In particular, many provinces in Thailand have become the investment and tourism destinations for many foreigners, and Ranong is one of these provinces. Ranong is a beautiful province located in the Southern part of Thailand. It has abundant natural resources and it is especially famous for its natural mineral water.

The vision of Ranong is "To be the center of international transportation on the Andaman coast and to be a city of health tourism and livable environment (Provincial Community Development Office of Ranong, 2010). Thus, Ranong is an emerging city which is strategically located, thus, there are lots of job opportunities available for Thai workforce with various skills and qualifications.

However, as it was reported in the first quarter of 2017 , the unemployment rate in Ranong area was $0.36 \%$ which is an increase from the level of $0.28 \%$ as of the fourth quarter of 2016 (Ranong Province Labour Office, 2017). One of the reasons why Thai labor unemployment rate has increased is the replacement by migrant workers. This partially 
happened because migrant workers are often alright with cheaper labor wages but also because they usually have much better English skills as compared to the local/Thai workforce.

Under such circumstances in the province, English has been gaining the increasing importance for the Thai workplace. This has become the key reason why we have decided to conduct this research study on Thai labor requirements when it comes to developing English communication skills in Ranong province. We have been expecting to obtain useful information on the development of the local human capital through the development of English language skills among the local population. We are convinced this would be beneficial for the whole social group of Thai laborers in Ranong Province (and Thailand as a whole).

Thus, this research aims to study the content requirements to improvement of English communication skills among Thai laborers who are preparing to enter the labor market in Ranong Province, Thailand.

\section{Literature review}

\section{Human capital theory and concepts}

Human capital refers to the know-how, capabilities, skills and expertise of members belonging to an organization (Dzinkowski, 2000). According to the World Bank (1995), human capital can be defined as the skills that are inherent in a person or part of a workforce derived from improving health, nutrition, education and training while the other part comes from the experience that people use to increase the level of productivity in products and services. Back in 1960, Gary Becker, the Nobel Prize winner for Economics, pioneered the debate about human capital, in this debate he was stemming from the macroeconomic theory. He claimed that education and training are the most important investments when it comes to the development of human capital. Becker's vision on human capital growth is that it leads to the quality of products and services which can be divided into three main components as follows:

1) an investment in employee's skills and knowledge development has proven to increase productivity over cost;

2) organization should invest in employees' specific skills and knowledge development while employees should improve general skills on their own;

3) organization needs to protect human capital from being transferred to another company.

In order to maximize both employee and organizational performance, the human capital theory also explains the positive relationship between human resource practice and human resources retention.

Human capital theory continues with the idea that human resources can be divided into quantitative and qualitative ones. In its quantitative aspect, human capital concerns the amount of population and/or the number of working hours while knowledge, skills, and other factors affecting human productivity are considered to belong to the qualitative part. Quality of human resources can be enhanced by investing in individuals which, in its turn, would 


\section{THAI LABOR'S REQUIREMENTS FOR}

lead to the improved capability to earn more and to increase productivity rate at the same time.

Human capital theory explains how to decide how much capital needs to be invested in people for the purposes of maximizing the return on investment. Moreover, this theoretical concept considers "human as one type of capital" but the difference is that human capital is in the "abstract" form because skills and knowledge are indivisible and inseparable from their "owner". Training is therefore the key cause of any significant changes in human capital (Kiranantha, 1976).

\section{English language skill theory and concepts}

According to (Sangngern, 2008) and quite many other authors, all English language skills can be divided into: listening, speaking, reading, and writing. Any individual can develop the mentioned skills through learning and practice while the level of communication ability could be divided into 5 levels:

Level 1 - a person is able to speak, write, read and listen to English at an elementary level and can basically communicate in English;

Level 2 - the Level 1 skills and also a person is able to speak, write, read and listen to English and is able to understand the key essence of the content.

Level 3 - Level 2 skills and also a person is able to use English in communication and within their workplace using grammatically correct word combinations;

Level 4 - Level 3 skills and also a person is able to understand and use English idioms in various situations while all word constructions are both grammatically and substantively correct.

Level 5 - Level 4 skills + the person has enough skills and proficiency to use profound English which sounds close to native speakers. Communication is fluent and also specific and technical vocabulary are easily applied when it comes to a specialized field.

According to (Thatthong, 2004), the combination of language skills that learners need in the process of studying are speaking and writing, while they should use reading and listening as the channels of communication. Therefore, communication can be integrated in three ways as follows:1) integration of speaking a language with listening and reading skills; 2) integration of writing with listening and reading skills; and 3) integration of speaking and writing with various forms of communication. This clearly shows that language integration happens only when integration takes place between listening, speaking, and reading. The focus is, however, on the thinking process that occurs to the learner while performing various related activities and understanding things that he/she is learning.

\section{Methodology}

This study is a qualitative research since the researchers have used the method of indepth interviews as a research instrument. Other research details have been as follows:

1. The area of study has covered the territory of Ranong city, Thailand.

2. Our key informants have been 20 people, they have been divided into 2 groups: 10 unemployed people and then also 10 high-school students and university students. The researchers have been applying the method of purposive sampling and eventually have come to the conclusion that high-school level as the minimum qualification needed for participation in such interviews. 
3. Research instruments have been applied in the following order: 1) first, we have reviewed all related theories, concepts and principles; 2) then determined the objectives of this research; 3) identified the most topical issues and formulated the interview questions so that to cover both the scope of this research study and the most topical issues for future interviewees; 4) later we reviewed the interview questions following the recommendations put forward by the experts in the related fields.

The interview questions were all open-ended questions that can be divided into two parts.

Part 1: general information on the key informants including age, gender, income, education level, working experience, and the period of unemployment.

Part 2: questions concerning Thai labor requirements in the context of developing English communication skills necessary as part of preparation to enter the local labor market.

4. Data collection has been carried out through the following steps: 1) studying the related documentary research; 2) interviews carried out using the in-depth interview method. All data was collected during November 2017.

5. Data analysis processes were as follows: 1) basic data analysis has been done straight after the actual data collection; 2) then we reviewed the interview results from the recordings so that to single out the most important data that is directly related to the objectives of our study; 3 ) finally, all results have been categorized into the groups.

6. The researchers apply the triangulation method to check data using the same interview questions with the key informants but from different sources this time and then compared that data obtained. For example, we have carried out data comparison between the students from different schools as well as compared the data provided by the unemployed workers and university students to confirm accuracy and reliability of the data. At this, our intention was to verify whether all collected information is correct.

7. Protection of the key informants' rights and the researchers' roles. The researchers did their best to pay attention to the research ethics since the very beginning of this study. More specifically, the following actions have been taken: 1) the researchers introduced themselves to the respondents and then declared clearly the purposes of their research; 2) the researchers asked explicitly for collaboration on the interviewees' side and also requested individual permissions to record the whole process of interviewing; 3) The researchers have never used (and have no plans to do so in the future) the data obtained in the course of these interviews for the wrong propose. No information provided by the interviewees had negative or damaging effects on the contributors. If, at any point of time, the data providers felt it was not convenient for them to answer any of the questions included into our in-depth interviews - they were able to decline to answer.

\section{Results}

The findings of this study have helped us reveal the key content requirements when it comes to improving the English communication skills of Thai laborers and also students who are preparing to (re)enter the labor market in Ranong Province. We have decided to categorize 4 groups of skills as follows: 


\section{THAI LABOR'S REQUIREMENTS FOR}

English listening skills:

The key informants state that the problems with English listening skills they are facing concern difficulties with poor vocabulary mostly as they do not know many words and technical terminology especially which would have been handy for nearly any potential workplace. This leads to a significant communication struggle. Several quotes as examples: "I do not understand what they [employers] say because I do not know the meaning of the words" (Mr. A, 14 November 2017); "I have little knowledge of vocabulary at work" (Mr. R, 14 November 2017).

Another problem often mentioned by Thai laborers is the accent of the speaker. For example: "I have hard time when I have to work with a lot of foreigners because they have different pronunciation" (Ms. J, 15 November 2017).

The major problem about poor English listening skills of Thai workers is that listening is often required to get at least the basic instruction and orders at work, and this would impossible without basic listening skill. All interviewed workers are fully aware of the fact that following the instructions and orders at work is highly important. For instance: "I want to learn about how to get the work done more effectively" (Ms. D, 14 November 2017) or "I think it is very important to understand what the boss says to me and what he tells me to do" (Ms. S, 14 November 2017).

English speaking skills:

The key informants mention that the problems with English speaking skills they confront come mostly from the wrong usage of grammar. Our interviewees often do not know how to construct sentences and how to use English grammar. For example: "I always cannot convey my intentions very well because I am not sure know how to create a sentence" (Ms. A, 15 November 2017) and "I am very confused how to use English tenses" (Mr. J, 14 November 2017).

Another problem several times mentioned by Thai workers in the interviews is that they do not have enough confidence in speaking English. For example: "I am too shy to speak English because I am afraid that people will make fun of me" (Ms. B, 15 November 2017).

When it comes to speaking what Thai workers need to learn first and foremost is basic job interviewing skills, at least answering the most typical questions which might occur during a job interview. Some of them mention directly that being able to speak up during a job interview is a promising beginning of a career. For instance: "Ranong nowadays has many jobs that require you to speak English and I think when you already get employed you can always improve your skills then but the problem is you have to do well when you are applying for a job" (Ms. S, 14 November 2017).

\section{English reading skills:}

The key informants explain that their problems with English reading skills concern the aspect of interpretation mostly. They claim that English language has a different way to interpret the message as compared to Thai language. For example: "Reading is very difficult for me because it is easy to get things wrong and I usually do not know what is the main idea or an important message" (Ms. D, 14 November 2017) and "Thai language is less complicated in terms of interpretation" (Mr. R, 14 November 2017). 
Another problem that Thai workers mention is about grammar and vocabulary difficulties while reading. For example: "I search the meaning of the words in dictionary" (Ms. K, 15 November 2017) and "If the sentence is too long and complicated, I cannot understand at all. Especially if it concerns very important things, like legal issues. Then I am so stressed" (Ms. J, 15 November 2017).

English reading skills are so needed for Thai workers because this is the only to read job advertisements with the most promising work offers. Poor reading skills also do not let them fully understand what are the initial employers' requirements to job applicants. For instance: "It would be great if I knew in advance that my qualifications match the job" (Ms. S, 14 November 2017) and "I need to know what they need from me to prepare before applying for the job" (Mr. O, 14 November 2017).

\section{English writing skills:}

The key informants reveal that the major problems with English writing skills are related to grammar, vocabulary, and spelling. For example: "I am not sure I write correctly in terms of grammar" (Ms. B, 15 November 2017) and "I always spell the words in a wrong way" (Ms. S, 14 November 2017).

Writing in English is vital for Thai workers because sooner or later they all would need to fill out a job application form. For instance: "I have problems when I have to fill out application form so I always ask for help" (Mr. R, 14 November 2017) and "I can fill out only my basic information other than that I cannot do well" (Mr. A, 14 November 2017).

\section{Conclusions and Discussion}

The findings of this study demonstrate that overall, Thai workers are fully aware they are having difficulties with all four skills. The research findings reveal that Thai workers have most of the trouble with speaking and mostly because of the wrong usage of English grammar. This is very similar to what was concluded in (Low, 2014) who also noted that majority of frontdesk employees in the hotel industry of Pattaya Province have English speaking difficulties due to grammatical errors.

As for the listening skills, Thai workers have problems with understanding different accents in English. This was also mentioned as a frequent problem in the research findings of (Hiranburana, 2017) who studied how English is used in Thai workplaces. Additionally, we can also refer to the study of (Ayuwat and Tanee, 2005) who mentioned that $91.5 \%$ of the organizations in the Northeast of Thailand want their employees to improve English language skills and first of all they need their hires to be able to speak and listen.

The content requirements when it comes to improvement of English communication skills of Thai laborers in Ranong region may be different, depending on a particular set of skills they need to develop for a specific profession and/or job position. This is fully consistent with the study presented by Yongyingprasert (2016) who also noted that English communication and performance of the employees within the automotive service business at the operational level is closely associated and differentiated depending on a type of work operations. This difference is quite large between supervisors and workers, and also among workers themselves. 


\section{THAI LABOR'S REQUIREMENTS FOR}

Overall, we can sum up that English skills' improvement should focus on all the aspects of speaking, reading, writing and listening since all four categories of language skills will eventually have only positive impact on the quality of work (Ninaroon, 2014).

\section{Suggestions}

Both public and private organizations in Ranong Province could find the outcomes of this study useful. They may also choose to adjust our conclusions and recommendations per their specific plans of recruiting and labor development.

The results of this study could be used as a guideline when promoting English proficiency among Thai laborers and students; and also when developing the state/regional programs aimed at improving English communication skills of the local labor force.

Our suggestions for immediate implementation would be as follows:

1. The Government sector in Ranong Province should recognize the importance of Thai workforce for the economic development of the region and thus - also recognizing that their problems with English language communications would inevitably have its negative impact on the whole region. Thus, the public sector should develop and provide various training programs to help local people prepare for the job market. This can become an additional competitive advantage of the whole province and also of the Thai laborers when it comes to competition with migrants over job vacancies.

2. Private organizations in Ranong should also understand the difficulties with using English language by Thai laborers. To the extent possible, the local private sector should provide more opportunities to improve the language skills when they hire people. Businesses need to keep in mind that knowing English, in many cases, is the basis for human capital development in general.

3. Schools and universities in Ranong Province should prepare their students to have proper English skills. English-for-work courses should be developed and introduced into the curriculum of both schools and universities.

\section{Acknowledgement}

The authors would like to thank the Research and Development Institute, Suan Sunandha Rajabhat University, Bangkok, Thailand for financial support.

\section{References:}

Ayuwat, D. \& Tanee, T. (2005). Need of ability and skill of foreign language use by enterprises and organizations in the Northeast Thailand. Asia-Pacific Journal of Science and Technology, 11(4). 328-339.

Dzinkowski, R. (2000). The measurement and management of intellectual capital: An introduction. Management Accounting, 78(2). 32-36.

Hiranburana, K. (2017). Use of English in the Thai workplace. Kasetsart Journal of Social Sciences, 38. 31-38.

Kiranantha, T. (1976). Human Resource Economics and Manpower. Thai Watana Panich.

Low, P. (2014). Front Desk Skills Development: English Usages, Problems, and Needs. Humanities and Social Sciences Review, 3(4). 225-233. 
Marimuthu, M., Arokiasamy, L. \& Ismail, M. (2009). Human capital development and its impact on firm performance: Evidence from developmental economics. The Journal of International Social Research, 2(8). 265-272.

Ninaroon, P. \& Jadesadaluk, V. (2014). The Study Influence on Potentiality of Management for Alien Labor Affecting Effectiveness in Management of Human Resource and Performance of Entrepreneurs in Ranong Province. Thammasat Journal, 33(3). 19-48

Provincial Community Development Office of Ranong. [Online]. Available: http://ranong.cdd.go.th/?lang=en

$\begin{array}{lllll}\text { Sangngern, } & \text { B. } & \text { (2008). } & \text { English } & \text { language } \\ \text { skill.. Available: }\end{array}$ http://www.bu.ac.th/knowledgecenter/executive_journal/jan_june_14/pdf/aw09.pdf

Son, H. (2010). Human Capital Development. Asian Development Review, 27 (2). Available at: https://ssrn.com/abstract=1821984

Thatthong, K. (2004). Local area development program: Phetkasem Printing.

Yongyingprasert, W. (2016). English Language Enhancement for Staff Automotive Service Businesses For ASEAN Community. The $8^{\text {th }}$ Rajamangala University of Technology Phra Nakhon Academic National Conference.

Paper submitted

Paper accepted for publishing

Paper published online
04 August 2018

21 September 2018

30 November 2018 